to be three miles apart. One has an area of about one square mile and the other one and a half square miles.

In the past, a great earthquake occurred in the State of Cutch on June 16, 1819. This earthquake caused damage over a vast area and extensive changes in level in the crust of the earth. In Bhuj nearly 7,000 houses were overthrown and 1,140 bodies taken from the ruins. Half the town of Anjar was also destroyed with large loss of life. More recently, earthquakes have also occurred in Baluchistan in 1919 and 1931 (Nature, April 27, 1935, p. 661). It appears fortunate that the recent earthquake occurred beneath the sea some miles from land, as otherwise, with a shock so tremendous, without doubt there would have been enormous damage to property and loss of life.

\section{A Biological Council}

MANY biologists have felt for some time past that the activities of the specialized societies to which they belong remain largely unknown to other biologists who happen to belong to different societies or associations, although often the activities of these other societies are of direct interest to them. The officers of various biological societies have frequently felt the need for more information about the arrangements made by their fellows so as to avoid unnecessary clashes of dates of meetings or duplication of discussions on subjects that might advantageously form the basis of a joint meeting. In an endeavour to provide some common meeting ground for the representatives of the various biological societies, the Committee of the Biochemical Society in the autumn of 1944 called an informal meeting of representatives of a few societies which it was thought might be interested in the proposal. In all, three meetings, attended by representatives of fourteen biological societies, were held afterwards in the rooms of the Royal Society.

It was finally decided that a Biological Council should be formed consisting of the representatives of the various societies which were sympathetic to the scheme. The first meeting of this Council, at which Sir Henry Dale took the chair, was held recently in the Linnean Society's rooms. Dr. W. P. K. Findlay, of the Forest Products Laboratory, Princes Risborough, Dr. W. T. J. Morgan, of the Lister Institute of Preventive Medicine, London, and Prof. J. Z. Young, University College, London, were elected secretaries. While the immediate objects of the Council will probably be limited to such matters as the dates and subjects of the general meetings of societies, it is envisaged that the scope of the Council's work may enlarge and that many editorial and other problems relating to the societies' publications may fruitfully be discussed in common.

\section{Plant Pathology in Palestine}

ON the occasion of his seventieth birthday in November 1944, Prof. Chaim Weizmann was presented with a volume of researches by members of the Division of Plant Pathology of the Agricultural Research Station, Rehovoth, Palestine. This volume, describing researches carried out under war conditions, testifies to the zeal and energy of the phytopathological staff of the Station. The subjects dealt with cover a wide range, and include diseases of lettuce, beans, cucumbers, tomato, potatoes, citrus, cereals, clover, apple and pear scab, and fungicides. All the papers have since appeared in the Palestine
Journal of Botany, but the collection brought together is a worthy tribute to a great leader. The remarkable progress in agriculture effected by the Jews in Palestine has no doubt been greatly fostered by the help and assistance afforded by the work of the Agricultural Research Station at Rehovoth. Of the many interesting items mention, may be made of four only : a rare parasite of potatoes is constituted by powdery mildew, due to an unidentified species of Oidium, which first became epidemic in 1941, and again in 1942 and 1943 ; the occurrence of the apple and pear scab in all parts of Palestine but on local varieties only, as the European varieties are some weeks later in growth and regularly escape infection; the novel and ingenious suggestion of using the overhead system of irrigation, now largely in vogue in Palestine, for the application of fungicides; and the occurrence of Ustilago nigra on barley, the first record of this species of smut outside North America, and of immediate practical importance as this pathogen is susceptible to seed disinfectants.

\section{British Radio Industry}

The fundamental scientific principles of radiolocation and the startling results obtained from its application during the War have now become common knowledge. While the conception of this important new weapon is a tribute to British scientific research, and its success in practice demonstrates the ability of the Fighting Services to utilize a highly technical development, there is a necessary intermediate factor, which must not be forgotten, in the form of the design and production facilities available during the time of the country's direst need. The Radio Industry Council has dealt with this last aspect of the subject in a booklet recently issued under the title "The British Radio Industry in War and Peace" (Radio Industry Council, 59 Russell Square, London, W.C.1). The object of this small publication is to tell the world what British men of seience, engineers and workpeople have accomplished in the past five years in the application of the whole field of radio technique to war-time requirements, and the manner in which the experience gained during this terrific effort will be applied to the post-war development of broadcasting and television receiver production.

The British radio industry, which in 1935 produced nearly two million broadcasting receivers for ordinary listeners, was the main source of supply of the technical personnel required by the Services during the War to instal, operate and maintain radiolocation and communication equipment. In spite of this loss of some of its most valuable workers, the radio industry was called upon to supply, at high pressure, tremendous quantities of equipment and components of all types. A typical and impressive example of the scale of the radio equipment required is given by the fact that in any one of our thousand bomber raids many thousands of valves, cathode ray tubes and other electronic devices were in the air with those machines; while at the same time there were further very substantial quantities of all kinds of co-operating equipment in use on the ground. The Radio Industry Council has developed largely from the industry's war-time growth, and it is actively engaged in co-ordinating and furthering the interests of the whole radio manufacturing industry through the four independently constituted associations which deal respectively with the manufacture of valves, components, complete equipments and with general radio communications and electronic engineering. 